\title{
Hayekian Knowledge Problems in Organizational Theory
}

Foss, Kirsten; Foss, Nicolai J.

Document Version

Final published version

Publication date:

2008

License

CC BY-NC-ND

Citation for published version (APA):

Foss, K., \& Foss, N. J. (2008). Hayekian Knowledge Problems in Organizational Theory. Center for Strategic Management and Globalization. SMG Working Paper No. 14/2008

Link to publication in CBS Research Portal

\section{General rights}

Copyright and moral rights for the publications made accessible in the public portal are retained by the authors and/or other copyright owners and it is a condition of accessing publications that users recognise and abide by the legal requirements associated with these rights.

\section{Take down policy}

If you believe that this document breaches copyright please contact us (research.lib@cbs.dk) providing details, and we will remove access to the work immediately and investigate your claim. 


\section{HAYEKIAN KNOWLEDGE PROBLEMS}

IN ORGANIZATIONAL THEORY

Kirsten Foss

Nicolai J. Foss

SMG WP 14/2008

March 13, 2008 
SMG Working Paper No. 14/2008

March 13, 2008

ISBN: 978-87-91815-27-0

Center for Strategic Management and Globalization Copenhagen Business School

Porcelænshaven 24

2000 Frederiksberg

Denmark

www.cbs.dk/smg 


\title{
HAYEKIAN KNOWLEDGE PROBLEMS IN ORGANIZATIONAL THEORY
}

\author{
Kirsten Foss and Nicolai J Foss \\ Center for Strategic Management and Globalization \\ Copenhagen Business School \\ Porcelainshaven 24, 2000 Frederiksberg; Denmark \\ Kf.smg@cbs.dk ; njf.smg@cbs.dk
}

March 10, 2008; Word count (main body): 8,198

Prepared for a special issue of Organization Studies on "Austrian Economics and Organization Studies,” edited by Todd Chiles and Peter G. Klein

\section{Keywords}

Austrian economics, coordination, dispersed knowledge, authority, planning 


\title{
HAYEKIAN KNOWLEDGE PROBLEMS \\ IN ORGANIZATIONAL THEORY
}

\begin{abstract}
In his seminal 1945 essay Hayek argued that the dispersed nature of much commercially relevant knowledge places strong constraints on the feasibility of centralized allocation and coordination mechanisms, but that there remains a problem of making efficient use of such knowledge (the first Hayekian knowledge problem). He realized that firms, because they make use of authority, are also challenged by dispersed knowledge, and his emphasis on delegation as a response to dispersed knowledge may lead to the prediction that (large) firms shouldn’t exist. Yet (large) firms obviously do exist (the second Hayekian knowledge problem). Recently, many management and organizational scholars have echoed Hayek’s argument that centralized coordination mechanisms, such as authority, may fail in the presence of dispersed knowledge. We examine these modern arguments and argue that they rest on shaky foundations: dispersed knowledge is a less strong constraint on authority than is often thought. We examine the wider implications of this for knowledge-based arguments in management and organizational theory, and call for more research into the micro-foundations of such arguments.
\end{abstract}




\section{INTRODUCTION}

A small handful of papers have become highly influential in economics as well as in management and organization research. One such paper is Friedrich Hayek's 1945 essay, “The Use of Knowledge in Society,” a paper that emerged in the context of the debate on the viability and efficiency of planned resource allocation on the societal level (i.e., socialism) that raged among academic economists in (particularly) the inter-war period (Lavoie, 1985). Hayek (1945) famously argued that any economy-wide manager — a central planner — would be inherently constrained by the dispersed nature of knowledge in the economy. Planning confronts inherent knowledge-based constraints, and these constraints are certainly binding at a scale of activity that makes comprehensive overall management/planning of economy-wide resource allocation deeply inefficient.

Hayek's emphasis on the dispersed, subjectively held, fleeting, dispersed, and tacit nature of "knowledge in society" has been much cited in research on knowledge management (e.g., Nonaka and Takeuchi, 1995) and the knowledge-based view of the firm (e.g., Grant, 1996; Spender, 1996; Tsoukas, 1996). His fundamental argument that dispersed knowledge represents a constraint on centralized resource allocation has explicitly (Jensen and Meckling, 1992; Minkler, 1993; Foss, 1999; Sautet, 2000) and more implicitly (Nonaka and Takeuchi, 1995; Grant, 1996; Grandori, 1997, 2002) been applied to firm organization. Decentralization (in economies) and delegation (in firms) emerge to make efficient use of dispersed knowledge. However, consistent (or heavy-handed?) application of Hayek's decentralization argument leads to an apparent absurdity: if decentralization always and everywhere improves the utilization of dispersed knowledge, it would be hard to find any rooms for firms, and certainly for contemporary mega- 
sized firms. Firms must confront the exact same problem of making efficient use of dispersed knowledge that cannot be given to a central planner (Jensen and Meckling, 1992; Grant, 1996; Foss, 1999; Sautet, 2000). Efficient use of dispersed knowledge would seem to be a denial of firms, other than very small ones. Yet large firms exist. There seems then to be a problem of accounting for the existence of firms, given the dispersion of knowledge.

Hayek himself seems to have been aware of this explanatory problem. He refined a longstanding distinction in conservative and classical-liberal political philosophy between planned and unplanned orders (“taxis” and "kosmos,” respectively), recognizing that planned orders, such as firms, faced a “... problem which any attempt to bring order into complex human activities meets: the organizer must wish the individuals who are to cooperate to make use of knowledge that he himself does not possess” (Hayek, 1973: 49). Hayek’s solution to the problem was to apply his arguments that rules assist the coordination of dispersed knowledge, but with a modification: Whereas the rules that underlie spontaneous orders are abstract, applies to an unknown number of instances, and are undersigned, the rules that coordinate dispersed knowledge in designed orders are specific and designed. Implicitly, Hayek thought of the localized planning known as managerial authority as inefficient even for coordinating dispersed knowledge in firms; hence, his emphasis on rules, albeit designed ones, in firms. However, Hayek's solution to his second problem is not a satisfactory one: if designed rules with specific can solve the problem of making efficient use of dispersed knowledge in firms, why exactly is it that they cannot do this on the level of the economy at large? In other words, Hayek failed to address the issue in convincing comparative-institutional terms. 
Numerous modern management and organizational scholars have echoed Hayek's discussions of how dispersed knowledge constrains centralized allocation and coordination mechanism. Specifically, an influential argument is that managerial authority is compromised by dispersed knowledge conditions. To the extent that authority stops where the boundaries of the firm ends (Hart, 1995), this argument also has implications for firm boundaries. Our point in diagnosing and discussing two Hayekian knowledge problems is not to engage in doctrinal history but to derive implications for modern management and organizational thinking that links knowledge, authority and the boundaries of the firm. We examine these modern arguments and show that they rest on shaky foundations: dispersed knowledge is a less strong constraint on authority than is often thought. We discuss the implications of this for the knowledge-based theory of the firm.

\section{HAYEKIAN KNOWLEDGE ARGUMENTS}

\section{Hayek's Arguments}

The first argument that the nature of knowledge places a constraint on centralized resource allocation (per implication of any kind) was developed by Hayek $(1935,1945)$ in the context of the interwar debate on the economic efficiency of socialism (see Lavoie, 1985). In a often quoted passage (Hayek, 1945: 77-78), Hayek notes that

[t]he economic problem of society is ... not merely a problem of how to allocate "given" resources - if "given" is taken to mean given to a single mind which deliberately solves the problem set by these "data." It is rather a problem of how to secure the best use of resources known to any of the members of society, for ends whose relative importance only these individuals know. Or, to put it briefly, it is a problem of the utilization of 
knowledge which is not given to anyone in its totality.

This problem is aggravated by the fact that much of the important knowledge is tacit, fleeting and subjectively held. However, Hayek's emphasis on these characteristics of large parts of the knowledge that matters to decision-making and behavior was, however, only a means to an end. Thus, Hayek was driving at the identification of the "peculiar character of the problem of a rational economic order,” which, he argued, “... is determined precisely by the fact that the knowledge of the circumstances of which we must make use never exists in concentrated or integrated form but solely as the dispersed bits of incomplete and frequently contradictory knowledge which all the separate individuals possess" (Hayek, 1945: 77), and it is this fact that produces the "problem of the utilization of knowledge which is not given to anyone in its totality” (p.78). The solution that Hayek envisages to the problem is, of course, decentralization (that is, dispersed ownership rights) supported by a price system and various societal customs and norms ("rules") that assist the coordination of those plans and decisions that are independently made on the basis of local, fleeting, etc. knowledge (Hayek, 1945, 1973). These arguments have been immensely influential, particularly in comparative systems debates, and essentially gave the impetus to a whole sub-field in economics (i.e., mechanism design; e.g., Hurwicz, 1972).

In his early works, Hayek $(1935,1945)$ does not criticize the use of managerial authority in firms as a mechanism of coordination; his critical target lies on a much higher level of analysis, namely the notion that benevolent planners can draft complete plans for the allocation of resources on a societal level, based on all relevant knowledge being concentrated in the heads of a central planning bureau. Hayek provides a number of critical arguments against this notion: It may not be in managers interests to truthfully reveal information (Hayek, 1935); in a dynamic 
economy the process of communication between a center and individual managers is simply too slow and cumbersome for efficient adaptation (Hayek, 1945); and some knowledge cannot be communicated through the information technology applied by central planning due to its tacitness (Hayek, 1945, 1973). Thus, knowledge dispersal and the constraints this represents on planning is endogenous to the characteristics of knowledge and communication technology.

\section{The Application of Hayek’s Argument in Management and Organizational Thinking}

Much thinking on the exercise of managerial authority in organizations has implicitly or explicitly made strong assumptions about the knowledge held by managers. Thus, it is often assumed that managers are at least as (and often more) knowledgeable about relevant tasks as employees; that they can instruct the latter to carry out these tasks, and that they can somehow ascertain whether employees are sufficiently skilled to adequately carry out the task. It seems intuitive that the Hayekian argument represents a challenge to such assumptions, as explicitly argued by, for example, Nonaka and Takeuchi (1995) and Grant (1996). Specifically, the Hayekian challenge to the use of authority as a mechanism of coordination is this: how is it possible rationally to govern activities, such as work activities carried out by employees, by means of the authority mechanism when the holder of authority is partially ignorant about some, and potentially much, of the knowledge possessed by the employees, knowledge that may be vital for carrying out the relevant activities? ${ }^{1}$

\footnotetext{
${ }^{1}$ One immediate answer is that it is not, and that firms seek to homogenize the knowledge sets of their employees precisely in order to be able to avoid Hayekian knowledge problem, giving a strange Hayekian twist to Marglin's (1974) argument that firms exist to deskill employees (preserving “capitalistic” relations of production). Obviously, this is unlikely to be a satisfactory answer as we see large and viable firms control highly dispersed knowledge inside their corporate boundaries.
} 
Indeed, explicitly or implicitly numerous scholars in management and organizational have challenged the traditional view of managers' epistemic capabilities, deploying versions of Hayek’s knowledge-based critique of planning (e.g., Mintzberg, 1990; Grandori, 1997; Sharma, 1997; Brusoni, 2005). These scholars argue that if the knowledge that is essential in a work setting is partially unknown to the manager, dispersed across several employees, and perhaps even - because of its tacit nature - must remain unknown to the manager, the exercise of managerial authority is fundamentally compromised. In a nutshell managers cannot rationally direct work under such conditions when they lack the knowledge required to instruct and monitor employees. Grandori (2002: 257) argues that “[dispersed] knowledge causes authority (as a centralized decision-making system) to fail in all its forms.” Similar statements can be found in, for example, Minkler (1993), Cowen and Parker (1997), and Hodgson (1998). These authors explicitly invoke Hayek in support of their arguments.

The argument seems to be as follows. First, it is argued that authority — that is, the right to make decisions which guide the decisions of another person (Coase 1937; Simon 1951, 1991) — presupposes considerable knowledge about the knowledge (and perhaps also the action set) that is available to those that are being directed. ${ }^{2}$ Second, the presence of dispersed knowledge means that this condition cannot be fulfilled. Therefore, authority is an inefficient coordination mechanism, and alternative coordination mechanisms (Grandori, 2001) emerge to handle the coordination task implied by dispersed knowledge, such as prices (Hayek, 1945; Cowen and Parker, 1997), communication (Garicano, 2000), and norms (Grandori, 1997, 2002). Recall that

\footnotetext{
${ }^{2}$ Grandori (1997: 35) argues that “... whatever its basis, authority is a feasible governance mechanism only if information and competence relevant to solving economic action problems can be transferred to and handled by a single actor, a positive "zone of acceptance" exists, the actions of other supervised actors are observable, and if the system is not as large as to incur an overwhelming communication channel overload and control losses.”
} 
Hayek (1973) similarly argued that because planning and authority are not feasible mechanisms under dispersed knowledge conditions, firms must have resort to rules (albeit less abstract ones).

This argument may seem to acquire particularly force under the knowledge conditions that characterize the knowledge economy — specifically an increased need to source outside knowledge, rely on knowledge workers and engage in distributed innovation processes. These conditions would if anything seem to make knowledge more dispersed, and indeed many authors have argued exactly this, pointing out that firms increasingly need to rely on a growing number of knowledge specialists, inside as well as outside their boundaries (e.g., Coombs and Metcalfe, 2000; Wang and von Tunzelman, 2000; Brusoni, Prencipe and Pavitt, 2001; Orlikowski, 2002; Brusoni, 2005). This tendency strains the use of managerial authority as a mechanism of coordination (Grandori, 1997, 2002). ${ }^{3}$

However, the problem is a general one, and not specifically associated with the knowledge economy. Thus, Langlois (1995) develops a general argument that links thinking on firm capabilities to Hayekian arguments: Since firms as planned entities are inherently limited in the extent to which they can absorb, process and utilize knowledge — an idea that is reflected in the notion of "capability" — there are knowledge-based limits to the size and scope of firms. Related claims can be found in, for example, Kogut and Zander (1992) and Grant (1996). The foundations of these arguments are not entirely clear, but the Hayekian knowledge problem may underlie them: as managers can only rationally direct employees who make use of knowledge

\footnotetext{
${ }^{3}$ By "coordination," we mean consistency of plans (Hayek, 1937). By “coordination mechanisms," we refer to those mechanisms that may assure such plan-consistency, such as prices, authority, norms/rules/routines/standards/focal points (i.e., mechanisms that are based on behavioral regularities), consultation and ratiocination (e.g., in games). For an excellent discussion of coordination mechanisms and their implications for organizational theory, see Grandori (2001).
} 
that is familiar to those managers, the efficiency of managerial authority as a coordination is (somehow) constrained by the dis-similarity of knowledge that the firm tries to make use of (cf. Richardson, 1972). And the limits of managerial authority are identical to the boundaries of the firm (Hart, 1995; Williamson, 1996). Kirzner (1992: 162) nicely encapsulates this use of the Hayekian argument: "We may expect firms spontaneously to expand to the point where additional advantages of 'central' planning are just offset by the incremental knowledge difficulties that stem from dispersed information.”

\section{AUTHORITY AND KNOWLEDGE DISPERSAL ${ }^{4}$}

It is fair to say that most of those writers who have argued that dispersed knowledge is a force that impacts economic organization have generally failed to precisely define what is meant by knowledge being "dispersed" Similarly, the notion of "authority" usually also goes undefined. Finally, the precise mechanism through which the dispersed nature of knowledge constrains authority is not identified. In order to assess arguments relating dispersed knowledge to authority, it is necessary to look at the key constructs and how they relate in somewhat greater detail than what is usually done in the relevant literature.

\section{What is "Authority"? Two Simonian Concepts}

This is not the place to present a full review and critical evaluation of the multitude of definitions and ideas regarding the notion of authority existing in organizational theory (e.g., Weber, 1947; Thompson, 1956; Grandori, 2001). Neither is it is necessary as the above scholars all seem to have a rather traditional, bureaucratic conception of authority in mind, and not something like, for

\footnotetext{
${ }^{4}$ This section draws on Foss and Foss (2008).
} 
example, Weber's charismatic authority. To identify with this conception, it is useful to take a starting point in the concepts of authority offered by Simon $(1951,1991)$ in two papers, separated by four decades. These serve as useful starting points, because they are well known, precise, and do not invite confusions with neighbor concepts (e.g., leadership). However, they are also different.

Simon (1951) defines authority as obtaining when a "boss" is permitted by a "worker" to select actions, $\mathbf{A}^{0} \subset \mathbf{A}$, where $\mathbf{A}$ is the set of the worker's possible behaviors. More or less authority is then defined as making the set $\mathbf{A}^{0}$ larger or smaller. Simon develops a multi-period, incomplete contracts model with ex post governance. In the first period, the prospective worker decides whether to accept employment or not. Both parties know the possible set of actions and their associated expected and real costs and benefits, but none of the parties know which actions will be optimal, given circumstances. In the next period, the relevant circumstances are revealed to the boss. The boss then picks the action that he prefers and directs the worker to that action which — for the latter to accept the assignment — must lie within his or her "zone of acceptance.”

A worker's zone of acceptance is defined in Simon as that set of actions where the worker's expected costs of carrying out these actions do not exceed the agreed-upon on wage. An important feature of authority is that the authority of a superior is constrained by the acceptance of the subordinate of the authority. “A subordinate may be said to accept authority,” Simon (1951: 22) explains, “... whenever he permits his behavior to be guided by a decision reached by another, irrespective of his own judgment as to the merits of that decision." 5 That is, for some of the actions the costs to the worker may exceed the agreed-on wage, but acceptance of authority implies that the

\footnotetext{
${ }^{5}$ In contrast, in a market contract, the parties negotiate ex ante about the actions that the agent can take in response to various contingencies so as to fulfill the contract. Thus, the principal's flexibility under market contracting is limited compared to what it would be under authority.
} 
worker carries out those actions irrespectively of his own cost of doing so. ${ }^{6}$ The boss cannot commit to choose actions that maximize total surplus, and even if the worker is able to identify actions that yield a higher total surplus, he must carry out the action that is preferred by the boss. However, the boss never includes in the zone of acceptance those actions where the expected increase in wage to the worker exceeds his expected increase in benefits. ${ }^{7}$ In sum, Simon (1951) defines authority as a decision right that an employer acquires, because he expects to obtain only ex post contracting the relevant information that will make it possible for him to pick his preferred actions within a specified subset of actions, which he will then direct the employee to carry out. The underlying knowledge condition seems to be one of symmetric knowledge/information concerning contingencies. ${ }^{8}$

In Simon (1951, the employer grants no discretion with respect to the choice of actions. In actuality it is hard to imagine an authority relation where absolutely no discretion is granted to the employee. Even for the most closely monitored and repetitive work, some employee discretion will remain (Knight, 1921). Specifically, in the presence of costs of monitoring, the employer will grant de facto discretion to the employee. In other words, authority and employee discretion are not mutually exclusive. This was clearly recognized by Simon (1991: 31; our emph.) who argued that "[a]uthority in organizations is not used exclusively, or even mainly, to command specific actions." Instead, he explains, it is a command that takes the form of a result to be produced, a principle to be

\footnotetext{
${ }^{6}$ This is what makes the authority different from an agency relation. In the latter, the agent's participation constraint is never violated.

${ }^{7}$ Simon's explanation of authority and the employment relation is quite akin to Coase's (1937). In the presence of uncertainty, Coase argues, contingencies are costly to anticipate and describe in advance, and rather than negotiating on a spot market basis over each contingency as they arise, an employment contract is concluded. The latter is defined as "... one whereby the factor, for a certain remuneration (which may be fixed or fluctuating) agrees to obey the directions of an entrepreneur within certain limits. The essence of the contract is that it should only state the limits to the powers of the entrepreneur. Within these limits, he can therefore direct the other factors of production" (idem. 242).

${ }^{8}$ In contrast, in Coase (1937) the employer's knowledge about contingencies is superior to that of the employee.
} 
applied, or goal constraints, so that "[o]nly the end goal has been supplied by the command, and not the method of reaching it.”

Note that this definition allows for the delegation of discretion (Holmström, 1999). In a sense, this extension brings agency relations in hierarchies inside the orbit of authority relations, because it allows for the possibility that authority may (also) have the function of unilaterally changing the degree of delegation post contract agreement (see also Aghion and Tirole, 1997. Moreover, this second, more expansive notion of authority does not presuppose that the employer is at least as knowledgeable as the employee about how to best carry out a task. That is, an employer is able to direct or constrain employee actions in ways that benefit him, while allowing the existence of and possible use of knowledge held only by the employee.

Employers grant discretion to employees for a number of reasons, including economizing with principals’ opportunity costs (Salanié, 1997), improving motivation through “empowerment” (Conger and Canungo, 1988), fostering learning by providing more room for local explorative efforts and improving collective decision-making by letting more employees have an influence on decisions (Miller, 1992). Importantly, delegation is also granted in order to make efficient use of dispersed knowledge in firms, as Jensen and Meckling (1992) point out. As they also clarify, there is a cost side to delegation. This brings a further function of authority into focus, namely to constrain “the method[s] of reaching” an end goal, in Simon's (1991) terminology. Also, top-management keeps ultimate decision rights, so that it, if deemed necessary, can overrule decisions made on the basis of delegated decision rights (Foss, Foss and Vazquez, 2005). 
There are many reasons why employers constrain the discretion they delegate to employees. Employees are not full owners or residual claimants on the results of their decisions or do not share all relevant knowledge. Thus, delegation produces spillover effects (i.e., "externalities") that may be harmful to the employer and to overall firm performance.The relevant externalities include, but are by no means limited to, morally hazardous behavior (Holmström, 1979; Holmström and Milgrom, 1991). They also include coordination failures, such as scheduling problems, duplicative efforts (e.g., of information gathering, R\&D, etc.), cannibalization of product markets and other instances of decentralized actions being inconsistent with the firm's overall aims, etc. One way to reduce such harmful externalities is to constrain decision rights and monitor their use (Fama and Jensen, 1983; Holmström and Milgrom, 1991). Such monitoring may lead to overruling of decisions made on the basis of delegated rights.

This suggests a rationale for authority that is quite different from the narrow one associated with Simon (1951) — namely, to define, delegate and constrain discretion. ${ }^{9}$ For example, the right to use an asset in certain ways may be delegated; however, it is understood that this right does not entail the right to use the asset in the service of a competitor firm, nor may the asset be used in a way that management perceives as being damaging to the firm. It is also understood that breaking this understanding will be sanctioned. Defining constraints also implies the rights to veto decisions made on the basis of delegated rights, and to withdraw delegated decision rights (this may be seen as a special case of constraining rights). Employees may have different benefits and costs depending on the particular delegation and constraining of discretion. In sum, in a more

\footnotetext{
${ }^{9}$ The rather considerable literature on delegation in organizations (e.g., Galbraith, 1974; Fama and Jensen, 1983; Jensen and Meckling, 1992) does not explain why delegation should be associated with the exercise of authority. Part of the reason may lie in the static nature of the analysis: All costs and benefits associated with delegation are
} 
inclusive reading (than in Simon, 1991), authority is a decision right that an employer acquires, because he expects to obtain only ex post contracting the relevant information that enable him to delegate discretion to employees and constraining such discretion in ways preferred by him and within a specified subset of actions. In this understanding, the holder of authority does not necessarily have complete information about the actions available to the employee given the level of delegation and constraints he chooses. As will be argued this means that authority in this sense can make be deployed to make efficient use of dispersed knowledge. However, clarifying the latter notion still remains.

\section{What is "Dispersed Knowledge"?}

Hayek's (1945) discussion of the use of knowledge in society has very been invoked by economists in the context of positioning discussions of asymmetric information. However, as Kirzner (1997) clarifies, when Hayek (and other Austrians) talks about "dispersed knowledge” they have more in mind than the mainstream economics notion of asymmetric information. First, dispersed knowledge goes beyond the dyads usually (if not always) considered in information economics, and refer to larger social systems. Second, dispersed knowledge implies genuine or "sheer" ignorance, in contrast to the standard treatment of asymmetric information, in which the parties' are quite knowledgeable about what they are ignorant about (e.g., while they do not know about the realization of some stochastic variable, they know the underlying distribution). It is not immediately clear how to characterize such knowledge conditions. However, the currently very influential notion of “distributed knowledge” (e.g., Cohen and Reagan 1996; Granstrand, Patel and Pavitt, 1997; Lessard and Zaheer, 1996; Gherardi, 1999) may serve as a candidate for adding 
precision to the notion of dispersed knowledge. Highly pertinent in the present context, Marengo (1995) and Tsoukas (1996) explicitly conceptualized the firm as a distributed knowledge system.

Distributed knowledge is a member of a set of concepts that denote how knowledge may be present in a social system. ${ }^{10}$ Loosely, knowledge is distributed when a group of agents knows something no single agent (completely) knows. Thus, the notions that firms (Tsoukas, 1996) or whole economies (Hayek, 1945, 1973) are distributed knowledge systems mean that the set of agents comprising these entities somehow can be said to collectively possess knowledge that no single agent possesses. This does not amount to asserting the existence of mysterious supraindividual "collective minds." Knowledge still ultimately resides in the heads of individuals; however, when this knowledge is somehow combined, it means that considered as a system, the agents possess knowledge that they do not possess if separated.

Based on Hintikka (1962), Gerbrandy (1998) defines distributed knowledge in propositional terms in the following way: If $K_{i} p_{i}$ means that agent $i$ knows proposition $i$, a set of $n$ agents has distributed knowledge of a proposition q (i.e., Dq) when: $K_{1} p_{1} \wedge K_{2} p_{2} \wedge \ldots \wedge K_{n} p_{n} \Rightarrow$ $D q, q \neq p_{i}, \forall i$. For example, Peter knows that $\mathrm{p}$ is the case and Todd knows that $\mathrm{p}$ implies $\mathrm{y}$, but neither know that y is the case. However, if Peter and Todd's information states are "added" there is a sense, which is more than metaphorical, in which they may know that $\mathrm{y}$ is the case (Gerbrandy, 1998: 53). The information that $\mathrm{y}$ is the case is present in the system comprising except than perhaps monitoring the use of delegated decision rights.

${ }^{10}$ Two other members of the set are the game theory notions of "common knowledge" and "shared knowledge.” An event is common knowledge among a group of players if each player knows it, each one knows that the other players know it, each player knows that other players know that the other players know it and so on (Aumann, 1976). Shared knowledge differs from common knowledge by not requiring that each agent knows that the other agents know, etc. Thus, there is shared knowledge of a fact if each agent knows this fact, but does not know that the other agents know it. 
Peter and Todd, but in a distributed form. The definition is clearly open to some interpretation. At one extreme, Peter and Todd may both be completely ignorant about the knowledge controlled by the other party. ${ }^{11}$ At the other extreme, there is considerable, but not complete, ${ }^{12}$ knowledge overlap ( $p_{i}$ may be close in some sense to $p_{j}$ ). An implication is that distributed knowledge is consistent with asymmetric information. Between the extremes are different degrees of overlap between individual knowledge elements.

\section{DOES DISPERSED KNOWLEDGE MAKE AUTHORITY INEFFICIENT? ${ }^{13}$}

\section{An Example}

Discussions such as the one concerning how knowledge dispersal constrains authority have a tendency to lead to stark conclusions. However, the basis for such conclusions is not always entirely clear. Consider therefore a stylized example, specifically a contractual relation between Todd and Peter. Such a relation may be described in terms of elements of knowledge that the parties possess, specifically knowledge concerning actions, contingencies, outcomes, etc. Assume that the relevant knowledge is dispersed in the sense that while Todd has knowledge of some knowledge elements and Peter has knowledge of other elements that are relevant to their contractual relation, their respective knowledge is not overlapping. Specifically, Peter, the employee, can carry out two different actions, y and z. These actions lead to solving coordination

\footnotetext{
${ }^{11}$ Sometimes such an interpretation is made of the "competitive equilibrium" model in economics: Although knowledge of technologies and preferences is private, all this knowledge is utilized in the best possible way, so that the knowledge of how to bring about an allocation of resources with superior welfare properties is distributed in the economy (Makowski and Ostroy, 2001).

${ }^{12}$ If knowledge overlap is complete, the agents will also know or be able to infer q (if they have perfect rationality/perfect reasoning assumptions and/or the knowledge elements and how they connect is easy to comprehend).

${ }^{13}$ Parts of this section draw on Foss and Foss (2008).
} 
problems. The costs and benefit of these actions depend on the contingencies (p, b, q) that arise with certain probabilities during the contractual relationship. See Table 1 . The numbers in the cells show the expected benefit to the employer (Todd) from an action given a particular contingency (p,b,q) and the expected costs to Peter of carrying out the actions under the three different contingencies.

\section{Insert Table 1 Here}

The knowledge elements of relevance to the contractual relation concerns 1) the actions available to Peter; 2) the costs and benefits of carrying out these actions (i.e., the implications of [p, b, q] on the choice between y and z); 3) the different ways in which the actions can be carried out; 4) their associated costs and benefits; 5) the type of contingencies that can arise (p,b,q); 6) the probability that these contingencies arise; and 7) the actual contingencies that have emerged. To make distributed knowledge concrete, we can think of these elements as constituting the knowledge elements in the above definition of dispersed knowledge. The coordination problem consists of combining these knowledge elements in such a way that Peter chooses those actions that match the relevant contingencies.

In a perfect world with symmetric information, complete contingent contracts and/or with costless re-negotiation and contract enforcement, the problem would be easily solved, and all the value-maximizing actions would be chosen to match whatever contingency emerges. Given the specifications in Table 1, Todd will pick action $\mathrm{y}$ if contingency $\mathrm{b}$ emerges and action $\mathrm{z}$ if 
contingency p or q emerges, and order Peter to carry these out. The expected benefit to Todd of having authority is 112 and the expected cost to Peter 32, which is also the minimum flat wage he accepts for actions within this zone of acceptance (given an assumption of zero opportunity cost) The expected surplus from the authority relation is 80 . Thus, in a situation of symmetric information the parties may strike an employment contract in which Peter executes y or $\mathrm{z}$ depending on the benefit of these actions to Todd given the observed contingencies. Now introduce more “dispersed” knowledge conditions.

\section{Contracting Under Knowledge Dispersal}

Knowledge is dispersed when Peter and Todd have non-overlapping information sets on any of the above factors of importance to the contract. For example, Peter may know his costs of action, and Todd doesn't have a clue. Peter can then misrepresent the real costs in order to influence the sharing of the surplus. Such strategic misrepresenting can, of course, also happen in market contracts (and there are no systematic differences in incentives to do so depending on the type of contract). The employee's misrepresentation of costs may influence which actions the employer wants to include in the zone of acceptance; for this reason the employer may choose a market contract (outsourcing Peter's actions) rather than the employment contract he would have preferred in a setting of symmetric information. The same conclusion can be drawn if employees (agents) can act in a morally hazardous manner and choose to exert less effort in the actions they choose or that are chosen by the employer. If the knowledge dispersal concerns the probability of a contingency, and Todd is the informed party (Peter has no idea about the underlying distribution function), he can use this information strategically in the employment contract (as well as in an outsourcing relationship with Peter) to extract a greater share of the surplus. Thus, 
Todd can misrepresent the probability of a contingency that make him choose actions that are costly to Peter.

The consequences of dispersed knowledge are more difficult to track if there is asymmetric information about the actions ( $\mathrm{y}$ and $\mathrm{z}$ ) available to Peter and if this information is obtained by Peter post contracting. This may well be the situation many modern management and organizational scholars have in mind when they argue that authority cannot coordinate dispersed knowledge: Knowledge workers may possess knowledge of which actions are available and which are efficient that the employer has no clue about. Consider therefore the situation in which Todd does not know that $y$ is a solution to the coordination problem when contingency b arises. If he enters an employment contract, he will pick y if contingency $\mathrm{q}$ arises and $\mathrm{z}$ in all other cases. His surplus from entering that contract compared to the outsourcing contract with Peter (i.e., choosing $\mathrm{z}$ in all cases) is the difference between the wage and the created value from choosing $\mathrm{y}$ if contingency q arises — which may not be sufficient to make him choose the employment contract. Peter may not have incentives to inform Todd of these actions post contracting, since he is not interested in revealing actions where his costs are higher than the agreed upon fixed wage. Peter will not inform Todd about y as a contract solution should contingency q arise, but would do so should contingency p arise. However, neither does the agent in a market contract have incentives to inform the principal on actions that imply large costs relative to the payment for the job. Thus, if the employee obtains information about actions post contracting (and this is expected by the employer), it can positively influence the use of employment contracts and authority when the employer is able to take advantage of emergent actions where the costs to the employee are less than the agreed-upon wage without renegotiations. 
The employment contract is always efficient compared to the market contract if there is symmetric information on the actions and factors that effect costs and benefits to the parties of entering the contract, but Todd is in a better position to observe what contingency materialize. A different situation obtains if Todd can observe the contingencies ( $p, b, q)$, but Peter has the information on the actions available and on the costs and benefits of these actions (and Todd doesn't have a clue). In that case, Peter must be given discretion to make efficient use of the information.

Obviously, to be satisfactory a full analysis should consider the entire set of mechanisms that, in principle, are available to coordinate dispersed knowledge in terms of their net benefits. However, purpose of the above examples is merely to indicate that one should not simply jump to the conclusion that knowledge dispersal necessarily compromises the use of authority under an employment contract (in the sense of making it inefficient relative to market contracting). This may be extremely sensitive to the exact specification of dispersed knowledge.

\section{Dispersed Knowledge and Judgment}

From a different perspective, the "dispersed-knowledge-compromises-authority" argument arguably misconstrues the nature of managerial authority, because it is based on an epistemic fallacy. The fallacy lies in the argument that making rational decisions as a principal or employer concerning agents or employees presupposes full knowledge of their available action repertoire. Recall that Simon (1991) allowed for an expanded notion of authority according to which authority can be understood as a command that takes the form of a result to be produced, a principle to be applied, or goal constraints, so that while the end result may be described, the methods of reaching it are not. In actuality, this is no different from how most agents interact with 
specialized other agents in the market place. Thus, most of us non-plumbers usually don't know the full action set of the plumber, or what exactly to do in response to some calamity involving the plumbing of our house. Still, we do rely on our judgment of the plumber, possibly supplemented with reputational mechanisms. Market transactions do not break down when there is only partial knowledge overlap. By the same token, hierarchical mechanisms, involving authority, do not break down when there is only partial knowledge overlap. Exchange, whether in the market or inside firms, is perfectly possible in the face of ignorance.

Frank Knight (1921) very clearly recognized this. The arguably key concept in Knight is that of "judgment," that is, the ability to make decisions concerning resource uses in situations involving genuine uncertainty, that is, situations in which the range of outcomes and the probabilities of outcomes are unknown. More compactly, judgment is the human faculty that makes it possible for us to make decisions, even under severe ignorance. While Knight’s (1921) main interest in judgment lies in its role as a basis for a theory of profit and the firm, he understood very clearly that the effective exercise of authority does not require full knowledge of an employee's action set and precise knowledge of exactly which action should be picked in response to contingencies: "What we call 'control' consists mainly of selecting someone else to do the 'controlling.' Business judgment is chiefly judgment of men. We know things by knowledge of men who know them and control things in the same indirect way" (Knight 1921: 291). Delegation, Knight argues, rests on judgment (see Foss, Foss and Klein, 2007). Again, such judgment does not require that that the principal knows the employee's entire action set. Hierarchical organization is conceptualized by Knight as a layer of agents exercising judgment of subordinates' judgment (particularly 1921: 291-297), that is, nested judgment. 
An aspect of this is that managers specialize in exercising judgment. As an example, consider the following situation with dispersed knowledge: Todd knows that contingency b implies that Peter should carry out y and Will should carry out d, whereas contingency q implies that Will must never carry out d. Jane knows what contingencies emerge, but not the implications of these contingencies, and Peter and Will know the actions available to them. In such a setting, Todd acts as a coordinator, possessing the knowledge that if Peter, Will's and Jane's knowledge sets are somehow aggregated, this will result in their having, as a "system," a knowledge that none of them possesses individually and that this coordination of knowledge is needed in order to make efficient choices. Thus, although the coordinator may still be ignorant in an important sense about the knowledge controlled by Peter, Will and Jane she does not suffer from complete ignorance; there is some, possibly very modest, knowledge overlap. She may therefore be able to pass judgement on the overall abilities of Peter, Will and Jane, and, in particular, about how actions based on their knowledge may be coordinated. In other words, it is possible to have knowledge of types of interdependencies between actions based on different knowledge elements without possessing much knowledge of the actual interdependencies or the actions themselves.

\section{CONCLUDING DISCUSSION}

\section{Hayekian Knowledge Problems Redux}

As noted above Hayek's idea that the characteristics of knowledge constrains the (efficient) use of centralized allocation and coordination mechanisms has recently resonated strongly among management and organizational scholars. In addition to identifying the problem of how to make best use of dispersed knowledge on the level of the economy at large, Hayek also confronted the problem of how to explain how a planned order can make use of dispersed knowledge. He argued 
that the use of managerial authority is constrained by knowledge dispersal; however, Hayek pointed out that firms can make use of other coordination mechanisms: “... every organization must rely also on rules and not only on specific commands [i.e., authority]. The reason here is the same as that which makes it necessary for a spontaneous order to rely solely on rules: namely that by guiding the actions of individuals by rules rather than specific commands it is possible to make use of knowledge which nobody possesses as a whole” (1973: 48-49). Such rules are "rules for the performance of assigned tasks." They are therefore "necessarily subsidiary to commands” (1973: 49). In other words, firms may well exist under dispersed knowledge conditions - but it is then essentially because they substitute other mechanisms of coordination for managerial authority. Thus, Hayek seems inherently skeptical of any directed/planned process of resource allocation, whether at the level of the economy or at the level of the firm. As has been argued above, Hayek and those who have followed his lead here go too far: dispersed knowledge conditions do not necessarily imply that authority must be inefficient.

The argument in this paper has been that the Hayekian skepticism concerning the use of dispersed knowledge by means of authority is rooted in a too-narrow view of authority and in the epistemic fallacy that making use of knowledge requires, in effect, that the user himself possesses the relevant knowledge. The exercise of judgment and the possibility of delegation means that one can make efficient use of knowledge that one does not possess.

\section{Hayekian Knowledge Problems: A Black Box?}

Note also that Hayek fundamentally does not explain how the problem of making use of dispersed knowledge inside firms is resolved: If knowledge dispersal obtains, how can management choose good "rules for the performance of assigned tasks"? How are employees assigned to tasks 
and how are standards for performance chosen when these actions are partially dependent on knowledge that management does not hold itself? Etc. There seems to be a fundamental design problem here. Given Hayek's general evolutionary outlook, it seems warranted to suggest that this is done in the same way that societies discover rules, namely by trial-and-error processes, but Hayek is not forthcoming about this. As argued, however, an important function of managerial authority is exactly to delegate, assign employees to tasks, define goals, etc. — all in general not based on anything like perfect knowledge of employee capabilities and action sets, but on judgments of these. In other words, the extent to which dispersed knowledge constrains the use of managerial authority would seem to be dependent on managerial judgment.

Let us put this argument aside for the moment, and note instead that the discussion in this paper points to some general problems with Hayekian arguments concerning how dispersed knowledge constrains centralized resource allocation. The problem is not that they are wrong: What we have criticized in this paper is the extreme version that authority is inherently inefficient in the face of dispersed knowledge. But there are more subtle versions, such as Kirzner (1992: 162), who suggest that "the incremental knowledge difficulties that stem from dispersed information.” Such reasoning is consistent with Coase's (1937) argument that as firm size grows, "dissimilarity of transactions" increases, and this is one reason why management commits an increasing number of mistakes as firms grow. Richardson (1972) argues that "similar" transactions will tend to be organized inside firms whereas "dissimilar" transactions will be organized in markets or hybrids (depending on the degree of complementarity between the underlying capabilities). Knowledge-based scholars in strategic management and organization have made very similar arguments (e.g., Kogut and Zander, 1992). 
Such arguments may be seen as variations on the basic Hayekian theme, applied to the boundaries of the firm. In other words, while firms may make efficient use of knowledge that is dispersed inside their corporate boundaries, as they expand increasingly hierarchical failure related to knowledge dispersal sets in, and help determine the boundaries of the firm in a Coasian manner (Coase, 1937; see also Grant [1996] and Garicano [2000]). However, there are two fundamental (related) problems with these arguments. First, they neglect delegation. If it is accepted that managers can cope with dispersed knowledge by means of delegation (e.g., Jensen and Meckling, 1 992), why exactly should expanding the firm's boundaries lead to increasing "knowledge difficulties" (Kirzner, 1992)? Second, the arguments are essentially black box in character. Thus, the link between knowledge dispersal and hierarchical failure is not spelled out. The link may turn on the "similarity" and "dis-similarity" of transactions — so that more dispersed knowledge inside corporate hierarchies imply more dis-similar transactions, leading to more managerial errors and more mis-allocation, as suggested by Coase and Richardson — , but it is unfortunately unclear how this may be measured (but see Argyres [1996] for an attempt), and there is no existing discriminating alignment framework that assigns transactions to governance structures based on their knowledge characteristics (but see Grandori [1997, 2002] for some interesting suggestions).

In the recent knowledge-based theory of the firm much emphasis has been placed on tacitness as the key knowledge characteristic (Grant, 1996; Spender, 1996), a key argument being that tacit knowledge helps to determine the boundaries of the firm (Kogut and Zander, 1992). ${ }^{14}$ As

\footnotetext{
${ }^{14}$ Here is another interesting parallel to the socialist calculation debate, for when this debate was revived in doctrinal history and comparative systems discussions in the 1980s, much emphasis was placed on tacit knowledge and the inherent difficulties for a planning board of dealing with such knowledge (particularly Lavoie, 1985).
} 
Knight (1921) argued, firm hierarchies may make use of tacit knowledge because managerial judgment is to a large extent judgment of others' judgment, and knowledge-based writers echo Knight in stressing that firms may have unique advantages in making use of tacit knowledge (e.g., Demsetz, 1991; Kogut and Zander, 1992). Hayek’s (1945) argument is contrary: markets are in general capable of making better use of dispersed, tacit knowledge than hierarchies.

\section{Towards Micro-foundations for Knowledge Arguments}

To take stock, the reasoning so far has been that Hayekian knowledge-based arguments are contradicted by the argument that (Knightian) judgment and delegation allows for making use of dispersed knowledge. The Hayekian argument implies that markets generally make superior use of such knowledge, whereas the judgment and delegation argument implies that hierarchies may make efficient use of dispersed tacit knowledge. In fact, in some knowledge-based versions of the argument, hierarchies are claimed to be superior to markets concerning the use of tacit dispersed knowledge. Such opposing predictions indicate that knowledge-based arguments have not been satisfactorily worked out, fundamentally because there is no knowledge-based theory of organizational failure (cf. Nickerson and Zenger, 2004).

It is certainly possible to offer speculation here. For example, even if it is possible to make use of dispersed, tacit knowledge by means of managerial judgment and delegation, ultimately somebody has to make the final decisions. Foss, Foss and Klein (2007) in a related discussion make a distinction between "original” and "derived judgment." Original judgment is that exercised by the ultimate decision-maker, which Foss et al. identify with the entrepreneur, whereas derived judgment is the entrepreneurial initiative exercised by hierarchical subordinates to whom decision rights have been delegated. However, the ultimate decision-maker may, of 
course, may mistakes, notably concerning which activities to delegate to whom, etc. Thus, one may speculate that what ultimately constrains planned orders, such as firms, is how well this process is carried out, so that the ultimate constraint is the managerial judgment of the ultimate decision-maker. This takes us back to Kaldor's (1934) point that the ultimate constraint on firm size is the entrepreneurial fixed factor and to Coase's (1937) point that managerial error is a factor limiting the size of firms. However, this is still speculation. We still want to know what are the antecedents of such managerial errors, and how managerial errors depend on the characteristics of knowledge, etc. The research literature unfortunately offers very little leverage here. ${ }^{15}$

These problems indicate a more general problem, namely that there are no clear microfoundations for knowledge-based arguments (Foss, 2007). For example, it is not clear what is the fundamental unit of analysis, how this unit is dimensionalized, and how it (given some efficiency criterion) maps to governance structures and mechanisms. Our understanding of the faculty of “judgment” is incomplete. We know little about managerial ignorance (although some is known about biases to managerial decision-making), how this affects the quality of decision making and how this translates into organizational costs. We know little about how to conceptualize and measure the similarity/dis-similarity of knowledge. Etc.

In making a call for more research into such micro-issues, we suggest starting, not from Hayek (1945), but rather from Hayek (1937). In the latter paper, Hayek argued that the “... apparently subsidiary hypotheses or assumptions that people do learn from experience, and about how they acquire knowledge” (1937: 46) be offered significantly more attention in order to make economics an empirical science. Only small fractions of such a program have been addressed by

\footnotetext{
${ }^{15}$ Klein (1996) links managerial errors to the kind of calculation problems identified by Mises (rather than Hayek) in
} 
Hayek himself as well as later knowledge-based theorists. ${ }^{16}$ It is time, therefore, to re-open the research agenda that Hayek sketched in 1937 so as to gain an increased understanding of the arguments he made in 1945.

the calculation debate.

${ }^{16}$ In fact, it is arguable that Hayek sidestepped his own 1937 program in the 1945 paper. 


\section{REFERENCES}

Aghion, P. and Jean Tirole. 1997. "Formal and Real Authority in Organizations,” Journal of Political Economy 105: 1-29.

Aumann, Robert. 1976. “Agreeing to Disagree,” The Annals of Statistics 4: 1236-1239.

Brusoni, Stefano. 2005. "The Limits to Specialization: Problem Solving and Coordination in Modular Networks,” Organization Studies 26: 1885-1907.

Brusoni, Stefano, Andrea Prencipe, and Keith Pavitt. 2001. "Knowledge Specialization, Organizational Coupling, and the Boundaries of the Firm: Why Do Firms Know More Than They Make?,” Administrative Science Quarterly 46: 597-621.

Coase, Ronald H. 1937. “The Nature of the Firm,” in Nicolai J. Foss, ed. 1999. The Theory of the Firm: Critical Perspectives in Business and Management, Vol II. London: Routledge.

Cohen, Moshe and Robert A. Regan. 1996. "Managing Internal Consistency in Technology Intensive Design Projects,” Competitiveness Review 6: 42-59.

Conger, J. and R. Kanungo. 1988. “The Empowerment Process: Integrating Theory and Practice,” Academy of Management Review 13: 471-482.

Cowen, Tyler and David Parker. 1997. Markets in the Firm. London: Institute of Economic Affairs.

Demsetz, Harold. 1991. "The Nature of the Firm Revisited,” in Oliver E. Williamson and Sidney G. Winter, eds. 1991. The Nature of the Firm. Oxford: Blackwell.

Fama, Eugene and Michael C. Jensen 1983. ”Separation of Ownership and Control,” Journal of Law and Economics 26: 301-325.

Foss, Nicolai J. 1999. "The Use of Knowledge in Firms,” Journal of Institutional and Theoretical Economics 155: 458-486.

Foss, Nicolai J. 2005. Strategy and Organization in the Knowledge Economy. Oxford University Press.

Foss, Nicolai J. 2007. “The Knowledge Governance ～Approach,” Organization 14: 29-52.

Foss, Kirsten and Nicolai J. Foss. 2008. “Authority in the Context of Distributed Knowledge,” in Nicolai J. Foss and Snejina Michailova, eds. Knowledge Governance. Oxford: Oxford University Press.

Foss, Kirsten, Nicolai J. Foss, and Peter G. Klein. 2007. “Original and Derived Judgment: an Entrepreneurial Theory of Economic Organization,” Organization Studies 28: 1893-1912.

Foss, Kirsten, Nicolai Foss, and José Vasquez-Vicente. 2006. “Tying the Manager’s Hands: Credible Commitment and Firm Organization,” Cambridge Journal of Economics 30: 797818.

Foss, Nicolai J. 2007. “The Emerging Knowledge Governance Approach,” Organization 14: 29-52.

Garicano, Luis. 2000. "Hierarchies and the Organization of Knowledge in Production,” Journal of Political Economy 108: 874-904. 
Gerbrandy, Jelle Douwe. 1998. Bisimulations on Planet Kripke. Ph.d.-dissertation, Institute for Logic, Language and Computing, Amsterdam University.

Granstrand, Ove, Pari Patel, and Keith Pavitt. 1997. "Multitechnology Corporations: Why They Have 'Distributed' Rather Than 'Distinctive Core' Capabilities,' California Management Review 39 (4): 8-25.

Grant, Robert. 1996. “Toward a Knowledge-based Theory of the Firm,” Strategic Management Journal 17: 109-122.

Gherardi, Silvia. 1999. "Learning as Problem-driven or Learning in the Face of Mystery?," Organization Studies 20: 101-124.

Grandori, Anna. 1997. "Governance Structures, Coordination Mechanisms and Cognitive Models," Journal of Management and Governance 1: 29-42.

Grandori, Anna. 2001. Organizations and Economic Behavior. London: Routledge.

Grandori, Anna. 2002. “'Cognitive Failures' and Combinative Failures,” Journal of Management and Governance 6: 252-260.

Halpern, Joseph Y. and Yoram Moses. 1990. "Knowledge and Common Knowledge in a Distributed Environment”, Journal of the Association for Computing Machinery 37: 549-587.

Hart, Oliver. 1995. Firms, Contracts, and Financial Structure. Oxford: Oxford University Press.

Hayek, Friedrich A. 1935. „Socialist Calculation: the State of the Debate,“ in idem., 1948. Individualism and Economic Order. Chicago: University of Chicago Press.

Hayek, Friedrich A. von. 1937. "Economics and Knowledge,“ in idem. 1948. Individualism and Economic Order. Chicago: University of Chicago Press.

Hayek, Friedrich A. von. 1945. „The Use of Knowledge in Society,“ in idem. 1948. Individualism and Economic Order. Chicago: University of Chicago Press.

Hayek, Friedrich A. 1973. Law, Legislation and Liberty. Vol.1: Rules and Order. Chicago: University of Chicago Press.

Hintikka, J. 1962. Knowledge and Belief. Ithaca, NY: Cornell University Press.

Hodgson, Geoff. 1998. Economics and Utopia. London: Routledge.

Holmström, Bengt. 1979. “Moral Hazard and Observability,” Bell Journal of Economics 10: 74-91.

Holmström, Bengt. 1999. "The Firm as a Subeconomy," Journal of Law, Economics, and Organization 15: 74-102

Holmström, Bengt and Paul Milgrom. 1991. "Multitask Principal-Agent Analysis: Incentive Contracts, Asset Ownership and Job Design,” Journal of Law, Economics and Organization 7: 24-54.

Jensen, Michael C. and William H. Meckling. 1992. "Specific and General Knowledge and Organizational Structure,” in Lars Werin og Hans Wijkander, eds. 1992. Contract Economics. Oxford: Blackwell.

Kaldor, Nicholas. 1934. “The Equilibrium of the Firm,” Economic Journal 44: 60-76

Kirzner, Israel M. 1992. The Meaning of the Market Process. London: Routledge.

Kirzner, Israel M. 1997. "Entrepreneurial Discovery and the Competitive Market Process: an Austrian Approach,” Journal of Economic Literature 35: 60-85. 
Klein, Peter G. 1996. "Economic Calculation and the Limits of Organization,” Review of Austrian Economics 9: 3-28.

Knight, Frank H. 1921. Risk, Uncertainty, and Profit. Reprint 1965. New York: Augustus M. Kelley.

Langlois, Richard N. 1995. “Do Firms Plan?,” Constitutional Political Economy 6: 247-261.

Lavoie, Don. 1985. Rivalry and Central Planning. Cambridge: Cambridge University Press.

March, James G. and Herbert A. Simon. 1958. Organizations. New York: Wiley.

Marengo, Luigi. 1995. "Structure, Competence, and Learning in Organizations," Wirtschaftspolitische Blätter 6: 454-464.

Milgrom, Paul and John Roberts. 1992. Economics, Organization, and Management. Prentice-Hall.

Miller, Gary. 1992. Managerial Dilemmas. Cambridge: Cambridge University Press.

Minkler, Alanson P. 1993. “Knowledge and Internal Organization,” Journal of Economic Behavior and Organization 21: 17-30.

Mintzberg, Henry. 1990. "The Design School: Reconsidering the Basic Premises of Strategic Management,” Strategic Management Journal 11: 171-195.

Nickerson, Peterson and Todd Zenger. 2004. “A Knowledge-based Theory of the Firm - The Problem-solving Perspective,” Organization Science 15: 617-632.

Nonaka, I. and H. Takeuchi. 1995. The Knowledge-Creating Company. Oxford: Oxford University Press.

Richardson, George B. 1972. “The Organisation of Industry,” Economic Journal 82: 883-96.

Salanié, Bernard. 1997. The Economics of Contracts. Cambridge: MIT Press.

Sautet, Frederic. 2000. An Entrepreneurial Theory of the Firm. London: Routledge.

Sharma, Anurag. 1997. "Professional as Agent: Knowledge Asymmetry in Agency Exchange," Academy of Management Review 22: 758-798.

Simon, Herbert A. 1951. “A Formal Theory of the Employment Relationship,” in idem. 1982. Models of Bounded Rationality. Cambridge: MIT Press.

Simon, Herbert A. 1991. “Organizations and Markets,” Journal of Economic Perspectives 5: 25-44.

Spangler, William E. and James M. Peters. 2001. "A Model of Distributed Knowledge and Action in Complex Systems,” Decision Support Systems 31: 103

Tsoukas, Haridimos. 1996. "The Firm as a Distributed Knowledge System: a Constructionist Approach,” Strategic Management Journal 17: 11-25.

Wang, Q. and G.N. von Tunzelman. 2000. „Complexity and the Functions of the Firm: Breadth and Depth,“ Research Policy 29: 805-818.

Weber, Max. 1947. The Theory of Economic and Social Organization. New York: Oxford University Press.

Williamson, Oliver E. 1996. The Mechanisms of Governance. Oxford: Oxford University Press. 
TABLE 1:

\begin{tabular}{|l|l|l|c|c|}
\hline \multicolumn{4}{|c|}{ CONTINGENCIES AND THEIR PROBABILITIES } \\
\hline & & \multicolumn{1}{|c|}{$\begin{array}{c}\text { Contingency } \mathbf{p} \\
\mathbf{p}=. \mathbf{2}\end{array}$} & $\begin{array}{c}\text { Contingency b } \\
\mathbf{p = . 6}\end{array}$ & $\begin{array}{c}\text { Contingency } \mathbf{q} \\
\mathbf{p = . 2}\end{array}$ \\
\cline { 2 - 5 } & $\mathbf{Y}$ & $\begin{array}{l}\text { Expected benefit: } 6 \\
\text { Expected cost : } 6\end{array}$ & $\begin{array}{l}\text { Expected benefit: } 60 \\
\text { Expected cost: } 12\end{array}$ & $\begin{array}{l}\text { Expected benefit: } 32 \\
\text { Expected cost: } 10\end{array}$ \\
\cline { 2 - 5 } ACTIONS & $\mathbf{Z}$ & $\begin{array}{l}\text { Expected benefit: } 20 \\
\text { Expected cost: } 10\end{array}$ & $\begin{array}{l}\text { Expected benefit: } 48 \\
\text { Expected cost: } 7\end{array}$ & $\begin{array}{l}\text { Expected benefit : } 20 \\
\text { Expected cost: } 2.2\end{array}$ \\
\hline
\end{tabular}




\section{SMG - Working Papers \\ www.cbs.dk/smg \\ 2003}

2003-1: Nicolai J. Foss, Kenneth Husted, Snejina Michailova, and Torben Pedersen: Governing Knowledge Processes: Theoretical Foundations and Research Opportunities.

2003-2: Yves Doz, Nicolai J. Foss, Stefanie Lenway, Marjorie Lyles, Silvia Massini, Thomas P. Murtha and Torben Pedersen: Future Frontiers in International Management Research: Innovation, Knowledge Creation, and Change in Multinational Companies.

2003-3: Snejina Michailova and Kate Hutchings: The Impact of In-Groups and OutGroups on Knowledge Sharing in Russia and China CKG Working Paper.

2003-4: Nicolai J. Foss and Torben Pedersen: The MNC as a Knowledge Structure: The Roles of Knowledge Sources and Organizational Instruments in MNC Knowledge Management CKG Working Paper.

2003-5: Kirsten Foss, Nicolai J. Foss and Xosé H. Vázquez-Vicente: “Tying the Manager’s Hands": How Firms Can Make Credible Commitments That Make Opportunistic Managerial Intervention Less Likely CKG Working Paper.

2003-6: Marjorie Lyles, Torben Pedersen and Bent Petersen: Knowledge Gaps: The Case of Knowledge about Foreign Entry.

2003-7: Kirsten Foss and Nicolai J. Foss: The Limits to Designed Orders: Authority under "Distributed Knowledge" CKG Working Paper.

2003-8: Jens Gammelgaard and Torben Pedersen: Internal versus External Knowledge Sourcing of Subsidiaries - An Organizational Trade-Off.

2003-9: Kate Hutchings and Snejina Michailova: Facilitating Knowledge Sharing in Russian and Chinese Subsidiaries: The Importance of Groups and Personal Networks Accepted for publication in Journal of Knowledge Management.

2003-10: Volker Mahnke, Torben Pedersen and Markus Verzin: The Impact of Knowledge Management on MNC Subsidiary Performance: the Role of Absorptive Capacity CKG Working Paper.

2003-11: Tomas Hellström and Kenneth Husted: Mapping Knowledge and Intellectual Capital in Academic Environments: A Focus Group Study Accepted for publication in Journal of Intellectual Capital CKG Working Paper.

2003-12: Nicolai J Foss: Cognition and Motivation in the Theory of the Firm: Interaction or "Never the Twain Shall Meet"? Accepted for publication in Journal des Economistes et des Etudes Humaines CKG Working Paper.

2003-13: Dana Minbaeva and Snejina Michailova: Knowledge Transfer and Expatriation Practices in MNCs: The Role of Disseminative Capacity.

2003-14: Christian Vintergaard and Kenneth Husted: Enhancing Selective Capacity Through Venture Bases. 


\section{4}

2004-1: Nicolai J. Foss: Knowledge and Organization in the Theory of the Multinational Corporation: Some Foundational Issues

2004-2: Dana B. Minbaeva: HRM Practices and MNC Knowledge Transfer

2004-3: Bo Bernhard Nielsen and Snejina Michailova: Toward a Phase-Model of Global Knowledge Management Systems in Multinational Corporations

2004-4: Kirsten Foss \& Nicolai J Foss: The Next Step in the Evolution of the RBV: Integration with Transaction Cost Economics

2004-5: Teppo Felin \& Nicolai J. Foss: Methodological Individualism and the Organizational Capabilities Approach

2004-6: Jens Gammelgaard, Kenneth Husted, Snejina Michailova: Knowledge-sharing Behavior and Post-acquisition Integration Failure

2004-7: Jens Gammelgaard: Multinational Exploration of Acquired R\&D Activities

2004-8: Christoph Dörrenbächer \& Jens Gammelgaard: Subsidiary Upgrading? Strategic Inertia in the Development of German-owned Subsidiaries in Hungary

2004-9: Kirsten Foss \& Nicolai J. Foss: Resources and Transaction Costs: How the Economics of Property Rights Furthers the Resource-based View

2004-10: Jens Gammelgaard \& Thomas Ritter: The Knowledge Retrieval Matrix: Codification and Personification as Separate Strategies

2004-11: Nicolai J. Foss \& Peter G. Klein: Entrepreneurship and the Economic Theory of the Firm: Any Gains from Trade?

2004-12: Akshey Gupta \& Snejina Michailova: Knowledge Sharing in Knowledge-Intensive Firms: Opportunities and Limitations of Knowledge Codification

2004-13: Snejina Michailova \& Kate Hutchings: Knowledge Sharing and National Culture: A Comparison Between China and Russia

\section{5}

2005-1: Keld Laursen \& Ammon Salter: My Precious - The Role of Appropriability Strategies in Shaping Innovative Performance

2005-2: Nicolai J. Foss \& Peter G. Klein: The Theory of the Firm and Its Critics: A Stocktaking and Assessment

2005-3: Lars Bo Jeppesen \& Lars Frederiksen: Why Firm-Established User Communities Work for Innovation: The Personal Attributes of Innovative Users in the Case of Computer-Controlled Music

2005-4: Dana B. Minbaeva: Negative Impact of HRM Complementarity on Knowledge Transfer in MNCs

2005-5: Kirsten Foss, Nicolai J. Foss, Peter G. Klein \& Sandra K. Klein: Austrian Capital 
Theory and the Link Between Entrepreneurship and the Theory of the Firm

2005-1: Nicolai J. Foss: The Knowledge Governance Approach

2005-2: Torben J. Andersen: Capital Structure, Environmental Dynamism, Innovation Strategy, and Strategic Risk Management

2005-3: Torben J. Andersen: A Strategic Risk Management Framework for Multinational Enterprise

2005-4: Peter Holdt Christensen: Facilitating Knowledge Sharing: A Conceptual Framework

2005-5 Kirsten Foss \& Nicolai J. Foss: Hands Off! How Organizational Design Can Make Delegation Credible

2005-6 Marjorie A. Lyles, Torben Pedersen \& Bent Petersen: Closing the Knowledge Gap in Foreign Markets - A Learning Perspective

2005-7 Christian Geisler Asmussen, Torben Pedersen \& Bent Petersen: How do we Capture "Global Specialization" when Measuring Firms' Degree of internationalization?

2005-8 Kirsten Foss \& Nicolai J. Foss: Simon on Problem-Solving: Implications for New Organizational Forms

2005-9 Birgitte Grøgaard, Carmine Gioia \& Gabriel R.G. Benito: An Empirical Investigation of the Role of Industry Factors in the Internationalization Patterns of Firms

2005-10 Torben J. Andersen: The Performance and Risk Management Implications of Multinationality: An Industry Perspective

2005-11 Nicolai J. Foss: The Scientific Progress in Strategic Management: The case of the Resource-based view

2005-12 Koen H. Heimeriks: Alliance Capability as a Mediator Between Experience and Alliance Performance: An Empirical Investigation Into the Alliance Capability Development Process

2005-13 Koen H. Heimeriks, Geert Duysters \& Wim Vanhaverbeke: Developing Alliance Capabilities: An Empirical Study

2005-14 JC Spender: Management, Rational or Creative? A Knowledge-Based Discussion

\section{6}

2006-1: Nicolai J. Foss \& Peter G. Klein: The Emergence of the Modern Theory of the Firm

2006-2: Teppo Felin \& Nicolai J. Foss: Individuals and Organizations: Thoughts on a Micro-Foundations Project for Strategic Management and Organizational Analysis

2006-3: Volker Mahnke, Torben Pedersen \& Markus Venzin: Does Knowledge Sharing 
Pay? An MNC Subsidiary Perspective on Knowledge Outflows

2006-4: Torben Pedersen: Determining Factors of Subsidiary Development

2006-5 Ibuki Ishikawa: The Source of Competitive Advantage and Entrepreneurial Judgment in the RBV: Insights from the Austrian School Perspective

2006-6 Nicolai J. Foss \& Ibuki Ishikawa: Towards a Dynamic Resource-Based View: Insights from Austrian Capital and Entrepreneurship Theory

2006-7 Kirsten Foss \& Nicolai J. Foss: Entrepreneurship, Transaction Costs, and Resource Attributes

2006-8 Kirsten Foss, Nicolai J. Foss \& Peter G. Klein: Original and Derived Judgement: An Entrepreneurial Theory of Economic Organization

2006-9 Mia Reinholt: No More Polarization, Please! Towards a More Nuanced Perspective on Motivation in Organizations

2006-10 Angelika Lindstrand, Sara Melen \& Emilia Rovira: Turning social capital into business? A study of Swedish biotech firms' international expansion

2006-11 Christian Geisler Asmussen, Torben Pedersen \& Charles Dhanaraj: Evolution of Subsidiary Competences: Extending the Diamond Network Model

2006-12 John Holt, William R. Purcell, Sidney J. Gray \& Torben Pedersen: Decision Factors Influencing MNEs Regional Headquarters Location Selection Strategies

2006-13 Peter Maskell, Torben Pedersen, Bent Petersen \& Jens Dick-Nielsen: Learning Paths to Offshore Outsourcing - From Cost Reduction to Knowledge Seeking

2006-14 Christian Geisler Asmussen: Local, Regional or Global? Quantifying MNC Geographic Scope

2006-15 Christian Bjørnskov \& Nicolai J. Foss: Economic Freedom and Entrepreneurial Activity: Some Cross-Country Evidence

2006-16 Nicolai J. Foss \& Giampaolo Garzarelli: Institutions as Knowledge Capital: Ludwig M. Lachmann's Interpretative Institutionalism

2006-17 Koen H. Heimriks \& Jeffrey J. Reuer: How to Build Alliance Capabilities

2006-18 Nicolai J. Foss, Peter G. Klein, Yasemin Y. Kor \& Joseph T. Mahoney: Entrepreneurship, Subjectivism, and the Resource - Based View: Towards a New Synthesis

2006-19 Steven Globerman \& Bo B. Nielsen: Equity Versus Non-Equity International Strategic Alliances: The Role of Host Country Governance

\section{7}

2007-1 Peter Abell, Teppo Felin \& Nicolai J. Foss: Building Micro-Foundations for the Routines, Capabilities, and Performance Links 
2007-2 Michael W. Hansen, Torben Pedersen \& Bent Petersen: MNC Strategies and Linkage Effects in Developing Countries

2007-3 Niron Hashai, Christian G. Asmussen, Gabriel R.G. Benito \& Bent Petersen: Predicting the Diversity of Foreign Entry Modes

2007-4 Peter D. Ørberg Jensen \& Torben Pedersen: Whether and What to Offshore?

2007-5 Ram Mudambi \& Torben Pedersen: Agency Theory and Resource Dependency Theory: Complementary Explanations for Subsidiary Power in Multinational Corporations

2007-6 Nicolai J. Foss: Strategic Belief Management

2007-7 Nicolai J. Foss: Theory of Science Perspectives on Strategic Management Research: Debates and a Novel View

2007-8 Dana B. Minbaeva: HRM Practices and Knowledge Transfer in MNCs

2007-9 Nicolai J. Foss: Knowledge Governance in a Dynamic Global Context: The Center for Strategic Management and Globalization at the Copenhagen Business School

2007-10 Paola Gritti \& Nicolai J. Foss: Customer Satisfaction and Competencies: An Econometric Study of an Italian Bank

2007-11 Nicolai J. Foss \& Peter G. Klein: Organizational Governance

2007-12 Torben Juul Andersen \& Bo Berhard Nielsen: The Effective Ambidextrous Organization: A Model of Integrative Strategy Making Processes.

\section{8}

2008-1 Kirsten Foss \& Nicolai J. Foss: Managerial Authority When Knowledge is Distributed: A Knowledge Governance Perspective

2008-2 Nicolai J. Foss: Human Capital and Transaction Cost Economics.

2008-3 Nicolai J. Foss \& Peter G. Klein: Entrepreneurship and Heterogeneous Capital.

2008-4 Nicolai J. Foss \& Peter G. Klein: The Need for an Entrepreneurial Theory of the Firm.

2008-5 Nicolai J. Foss \& Peter G. Klein: Entrepreneurship: From Opportunity Discovery to Judgment.

2008-6 Mie Harder: How do Rewards and Management Styles Influence the Motivation to Share Knowledge?

2008-7 Bent Petersen, Lawrence S. Welch \& Gabriel R.G. Benito: Managing the Internalisation Process - A Theoretical Perspective.

2008-8 Torben Juul Andersen: Multinational Performance and Risk Management Effects: Capital Structure Contingencies. 
2008-9 Bo Bernard Nielsen: Strategic Fit and the Role of Contractual and Procedural Governance in Alliances: A Dynamic Perspective.

2008-10 Line Gry Knudsen \& Bo Bernhard Nielsen: Collaborative Capability in R\&D Alliances: Exploring the Link between Organizational and Individual level Factors.

2008-11 Torben Juul Andersen \& Mahesh P. Joshi: Strategic Orientations of Internationalizing Firms: A Comparative Analysis of Firms Operating in Technology Intensive and Common Goods Industries.

2008-12 Dana Minbaeva: HRM Practices Affecting Extrinsic and Intrinsic Motivation of Knowledge Receivers and their Effect on Intra-MNC Knowledge Transfer.

2008-13 Steen E. Navrbjerg \& Dana Minbaeva: HRM and IR in Multinational Corporations: Uneasy Bedfellows?

2008-14 Kirsten Foss \& Nicolai J. Foss: Hayekian Knowledge Problems in Organizational Theory. 